\title{
Multielement Determination of Macro and Micro Contents in Medicinal Plants and Phytomedicines from Brazil by ICP OES
}

\author{
Aníbal de F. Santos Júnior, ${ }^{*, a, b}$ Rafael A. Matos, ${ }^{a}$ Eberson M. J. Andrade, ${ }^{b}$ \\ Walter N. L. dos Santos, ${ }^{b, c}$ Hemerson I. F. Magalhães, ${ }^{d}$ Fernanda do N. Costa ${ }^{c}$ and \\ Maria das Graças A. Korn ${ }^{c}$
}

${ }^{a}$ Departamento de Ciências da Vida and ${ }^{b}$ Departamento de Ciências Exatas e da Terra, Universidade do Estado da Bahia, 41195-000 Salvador-BA, Brazil

'Instituto de Química,Universidade Federal da Bahia, Campus Ondina, 40170-290 Salvador-BA, Brazil

${ }^{d}$ Departamento de Ciências Farmacêuticas, Universidade Federal da Paraíba, 58051- 900 João Pessoa-PB, Brazil

\begin{abstract}
In this study, the elemental composition of nine medicinal plants and phytomedicines was evaluated by using axial view inductively coupled plasma optical emission spectrometry (ICP OES) after three digestion procedures: dry ashing (DA) and two wet digestions with a mineral acid $\left(\mathrm{HNO}_{3} / \mathrm{H}_{2} \mathrm{O}_{2}\right)$ mixture on a conventional hot plate $(\mathrm{CD})$, besides microwave digestion $(\mathrm{MW})$. Accuracy was assessed from spinach leaves (CRM 1570a) and recovery values were in the range of 82 to $113.8 \%$. Precisions, such as relative standard deviation (RSD), below $10 \%$ were reached. The MW procedure was preferred for its accuracy (recovery values of 94 to 102\%), reduced contamination, increase in the efficiency of the decomposition process, lower residual acidity and reduced time required for digestion. The concentrations of analytes in the samples (minimummaximum in $\left.\mu \mathrm{g} \mathrm{g}^{-1}\right)$ were: $\mathrm{Ca}(100.71-462.20)$, $\mathrm{Co}$ (0.54-0.85), $\mathrm{Cu}(0.32-7.82), \mathrm{Fe}$ (2.74-18.03), $\mathrm{Mg}$ (18.40-521.28), Mn (0.17-55.14), Ni (0.56-1.25) and $\mathrm{Zn}$ (2.96-20.92). The levels of Al, Ba, $\mathrm{Cd}, \mathrm{Cr}, \mathrm{Mo}, \mathrm{Pb}, \mathrm{Se}$ and $\mathrm{V}$ in all investigated samples were found to be below the limit of detection of ICP OES. The multielement analysis by ICP OES showed that the method is simple, fast and reliable for the multielement determination in medicinal plants and phytomedicines.
\end{abstract}

Keywords: medicinal plant, phytomedicines, sample preparation, elemental composition, ICP OES

\section{Introduction}

The use of medicinal plants for treatment, cure and prevention of diseases is one of the oldest forms of medical practice of humanity. The World Health Organization (WHO) reported that $65-80 \%$ of the population of developing countries is dependent on medicinal plants as the only way of access to basic health care. ${ }^{1}$

Metal contents are important in phytomedicines, due to their toxicological properties, as well as from the nutritional point of view. Phytomedicines are classified as nutritional supplements based on herbs and herbal plants and are an important source of nutrients (vitamins, minerals and aminoacids) ${ }^{2,3}$ There is much scientific interest in the

*e-mail: afjunior@uneb.br development of plant products such as dietary supplements and herbal formulations. ${ }^{4-6}$ However, these products need a better quality control ${ }^{7}$ due to the presence of potentially toxic and essential (macro and micro) elements, which can have harmful effects when their intake significantly exceeds the recommended amounts in herbs. ${ }^{8-11}$

For most of the analytical determinations from several biological samples, sample digestion is required. The selection of the optimum method for sample pretreatment is based on specific parameters, such as concentration of the analyzed metals, nature of the sample (solid, liquid, etc.) and type of matrix. ${ }^{12,13}$ Wet decomposition procedures (conventional or assisted by microwave radiation) are very efficient, allowing the combination of oxidizing acids (such as nitric, perchloric, and hydrochloric acids) with other oxidizing agents (such as hydrogen peroxide), since it leads 
to the complete or partial degradation of organic matter present in the samples. ${ }^{14}$ Different digestion equipment can be used: open beakers heated on hot plates, block digesters and digestion units placed in microwave ovens. ${ }^{15}$ Closed systems (microwave) for the digestion of solid samples containing acid mixtures or concentrated acids have been used in the determination of several elements in complex matrices. ${ }^{16-20}$

Spectrometric techniques of atomic absorption and emission, such as flame atomic absorption spectrometry $(\text { FAAS })^{21}$ and graphite furnace atomic absorption spectrometry (GF AAS), ${ }^{22}$ are largely used. Inductively coupled plasma optical emission spectrometry (ICP OES) ${ }^{23}$ and inductively coupled plasma mass spectrometry (ICP-MS $)^{24}$ are used for the determination of trace metals (concentration lower than $1 \mu \mathrm{g} \mathrm{mL} \mathrm{m}^{-1}$ ) in biological matrices due to high sensitivity, versatility, multielement analysis, ruggedness and speed of analysis. ${ }^{25}$

ICP OES is a technique that combines good quantitative multielement capability, wide linear dynamic ranges, good sensitivity, limited spectral and chemical interferences, low limits of detection and speed and ease of data handling and reporting with widespread (multiplevendor) instrument availability and reasonable cost. ${ }^{26}$ Due to its advantages, ICP OES has become one of the most used techniques for elemental determination, and many studies have been conducted to validate this method for metal analysis in biological samples. . $^{13,27-30}$

Thus, the aim of this study was to compare three different digestion procedures of medicinal plants prior to their multielement analysis by ICP OES. Dry ashing (DA) and two wet digestion procedures, conventional (CD) and assisted by microwave radiation (MW), were evaluated for macro $(\mathrm{Ca}$ and $\mathrm{Mg}$ ) and microelements (Al, Ba, Cd, Co, Cr, Cu, Fe, Mn, Mo, Ni, Pb, Se, V and $\mathrm{Zn}$ ), besides the determination by axial view ICP OES, in medicinal plants and phytomedicines: Maytenus ilicifolia Mart. ex Reiss ("espinheira santa"), Piper methysticum G. Foster (kawa-kawa), Pfaffia glomerata (Spreng.) Pedersen (Brazilian ginseng), Uncaria tomentosa (cat's claw), Rhamnus purshiana (sacred bark), Hypericum perforatum $\mathrm{L}$. (St. John's wort), Ptychopetalum olacoides Bentham ("marapuama"/potency wood), Anemopaegma arvense Vell. (“catuaba") and Euterpe oleracea Mart. (açaí).

\section{Experimental}

\section{Reagents and solutions}

Analytical grade reagents were used in the development of this study and all solutions were prepared using high-purity water obtained from a Milli-Q water purification system (Millipore, Bedford, USA). All laboratory material was decontaminated in a $10 \%\left(\mathrm{v} \mathrm{v}^{-1}\right) \mathrm{HNO}_{3}$ solution bath for $24 \mathrm{~h}$ and was rinsed with high-purity water. Subsequently, all materials were dried under clean-air conditions at room temperature.

All solvents and reagents were of the highest commercially available purity grade. Suprapur grade $65 \%(\mathrm{~m} / \mathrm{m}) \mathrm{HNO}_{3}$ and $30 \%(\mathrm{~m} / \mathrm{m}) \mathrm{H}_{2} \mathrm{O}_{2}$ (Merck, Darmstadt, Germany) were used for sample dissolution. Monoelemental high-purity grade $1 \mathrm{~g} \mathrm{~L}^{-1}$ stock solutions of $\mathrm{Al}, \mathrm{Ba}, \mathrm{Ca}, \mathrm{Cd}, \mathrm{Co}, \mathrm{Cr}, \mathrm{Cu}, \mathrm{Fe}, \mathrm{Mg}, \mathrm{Mn}, \mathrm{Mo}, \mathrm{Ni}, \mathrm{Pb}$, $\mathrm{Se}, \mathrm{Sn}, \mathrm{V}$ and $\mathrm{Zn}$ were also used. The calibration standards were prepared by diluting the stock multielemental standard solution (1000 $\left.\mathrm{mg} \mathrm{L}^{-1}\right)$ in $0.5 \%$ (v/v) nitric acid. The calibration curves for all the studied elements were in the range of 0.01 to $5.0 \mathrm{mg} \mathrm{L}^{-1}$. The purity of the plasma torch argon was higher than $99.99 \%$.

The samples of medicinal plants and phytomedicines, except for Hypericum perforatum L. (St. John's wort) and Rhamnuspurshiana (sacred bark), were provided by Herbarium Pharmaceutical Laboratory. Hypericum perforatum L. (St. John's wort) and Rhamnus purshiana (sacred bark) samples, commercially available in the form of capsules containing dry extract, were obtained from local drugstores in Salvador, Bahia, Brazil. All the samples were originally stored in closed plastic containers until analysis. A certified reference material, spinach leaves (CRM 1570a, from the National Institute of Standards and Technology (NIST, Gaithersburg, MD, USA)), was used to check the accuracy.

Instrumentation

The acid digestion of medicinal plants and phytomedicine samples was performed using a digester block Quimis TE 040/25 with analog temperature controller, up to 40 borosilicate microtubes and a commercial high-pressure laboratory microwave oven (Milestone Ethos 1600 Microwave Labstation, Sorisole, Italy) operating at a frequency of $2450 \mathrm{~Hz}$, with an energy output of $900 \mathrm{~W}$. This microwave digestion system was equipped with ten $100 \mathrm{~mL}$ tetrafluoromethoxy vessels and a ceramic vessel jacket. The maximum operating temperature, power and pressure were $180{ }^{\circ} \mathrm{C}, 1000 \mathrm{~W}$ and $100 \mathrm{bar}$, respectively, in $30 \mathrm{~min}$. Dry ashing was performed in a Quimis Q318S muffle furnace, with microprocessor ramp and dwell. Determinations were carried out using a Varian Vista (Mulgrave, Australia) simultaneous inductively coupled plasma optical emission spectrometry instrument with axial viewing, and a charge coupled device (CCD) detector was used as a comparative method. A Sturman-Master chamber and a VGroove 
nebulizer were also used. Metal determinations were carried out under manufacturer recommended conditions for power $(1.3 \mathrm{~kW})$, plasma gas flow $\left(15.0 \mathrm{~L} \mathrm{~min}^{-1}\right)$, auxiliary gas flow $\left(1.5 \mathrm{~L} \mathrm{~min}^{-1}\right)$ and nebulizer gas flow $\left(0.7 \mathrm{~L} \mathrm{~min}^{-1}\right)$. The emission lines for the analysis by ICP OES were chosen according to previous interference studies. The lines that exhibited low interference, high analytical signal and background ratios were selected. The following emission lines were used: $\mathrm{Al}^{\mathrm{I}} 396.152, \mathrm{Ba}^{\mathrm{I}} 455.403, \mathrm{Ca}^{\mathrm{II}} 396.847$, $\mathrm{Cd}^{\mathrm{I}} 228.802, \mathrm{Co}^{\mathrm{I}} 238.892, \mathrm{Cr}^{\mathrm{II}} 267.716, \mathrm{Cu}^{\mathrm{I}} 324.754$, $\mathrm{Fe}^{\mathrm{II}}$ 238.204, $\mathrm{Mg}^{\mathrm{II}}$ 279.553, $\mathrm{Mn}^{\mathrm{II}} 257.610, \mathrm{Mo}^{\mathrm{I}} 202.032$, $\mathrm{Ni}^{\mathrm{II}} 227.021, \mathrm{~Pb}^{\mathrm{I}}$ 217.000, $\mathrm{Se}^{\mathrm{I}} 196.026, \mathrm{~V}^{\mathrm{I}} 309.310$ and $\mathrm{Zn}^{\mathrm{I}} 213.857 \mathrm{~nm}$.

Preparation of medicinal plants and phytomedicines: digestion procedure

Dry ashing (DA) and two wet digestion systems, conventional (CD) and assisted by microwave radiation (MW), were proposed to analyze the samples. Dry ashing (calcination at $450-600^{\circ} \mathrm{C}$ ) was performed according to the Association of Official Analytical Chemists (AOAC). ${ }^{31}$ Approximately $1.5 \mathrm{~g}$ sample was transferred to a porcelain crucible and then submitted to incineration in a muffle furnace, adjusted to reach the temperature of $450{ }^{\circ} \mathrm{C}$ at a rate of $50^{\circ} \mathrm{Ch}^{-1}$ for $12 \mathrm{~h}$. The obtained ash was solubilized in $6 \mathrm{~mol} \mathrm{~L}^{-1} \mathrm{HCl}$ on a hot plate to evaporate. The residue was filtered through filter paper and the sample was then diluted to $20 \mathrm{~mL}$ with distilled water, in polypropylene tubes.

For wet digestion on a hot plate, a mixture of 5:1 $\mathrm{HNO}_{3} / \mathrm{H}_{2} \mathrm{O}_{2}$ was used in this study. For this procedure, the temperature was kept at $150{ }^{\circ} \mathrm{C}$ for $1 \mathrm{~h}$ during the digestion of $0.3 \mathrm{~g}$ plant sample. After cooling, $10 \mathrm{~mL}$ of distilled water were added to the sample and mixed. The residue was filtered through filter paper and the sample was then diluted to $10 \mathrm{~mL}$ with distilled water. Metal contents of the final solution were determined by ICP OES.

For microwave digestion, approximately $300 \mathrm{mg}$ of each phytomedicine sample were directly inserted into a microwave closed vessel. $1 \mathrm{~mL}$ of $30 \%\left(\mathrm{~m} \mathrm{~m}^{-1}\right) \mathrm{H}_{2} \mathrm{O}_{2}$ and $7.0 \mathrm{~mL}$ of $\mathrm{HNO}_{3}$ solutions were added to each vessel. The heating program was performed in four successive steps (Table 1).

After the digestion procedure and subsequent cooling, the digested samples were diluted to a final volume of $15.0 \mathrm{~mL}$ (micro) and $50.0 \mathrm{~mL}$ (macroelements) with water. Blanks were prepared in each sample batch. All experiments were performed in triplicate. The resulted solutions were analyzed by ICP OES.
Table 1. Operating conditions of a microwave digestion system

\begin{tabular}{lcccc}
\hline Stage & $\begin{array}{c}\text { time / } \\
\text { min }\end{array}$ & $\begin{array}{c}\text { Maximum } \\
\text { power / }\end{array}$ & $\begin{array}{c}\text { Temperature / } \\
{ }^{\circ} \mathrm{C}\end{array}$ & $\begin{array}{c}\text { Pressure / } \\
\text { bar }\end{array}$ \\
\hline 1 & 6 & 750 & 90 & 35 \\
2 & 4 & 750 & 90 & 35 \\
3 & 8 & 1000 & 180 & 35 \\
4 & 15 & 1000 & 180 & 35 \\
Ventilation & 20 & 0 & - & - \\
\hline
\end{tabular}

Determination of acidity and residual carbon of the digests

Digestion efficiency was evaluated by the determination of the residual carbon content (RCC) in digests. Acid-base titrations of the digests were performed to determine the final acidity of the samples. Titration was performed with a standard solution of sodium hydroxide $\left(0.09983 \mathrm{~mol} \mathrm{~L}^{-1}\right)$ and phenolphthalein $\left(1.0 \% \mathrm{~m} \mathrm{v}^{-1}\right.$ in ethanol). The standard solutions for the calibration curves were prepared at the same acid concentration of each digestion procedure.

The residual carbon was measured by ICP OES at $193.027 \mathrm{~nm}$. To determine the residual carbon content (RCC), the digested solutions were sonicated with an ultrasonic bath before the determination by ICP OES to remove any volatile carbon compounds that may have existed. The standard solutions for the calibration curves of the residual carbon were prepared with citric acid. $^{32}$

\section{Validation studies}

The method was validated by performance parameters: accuracy, precision, limits of detection (LOD) and of quantification (LOQ) and matrix effect. The accuracy of the measurements was assessed using spinach leaves certified reference material (CRM 1570a) from NIST. In addition, the accuracy of the methods was evaluated by addition and recovery tests, conducted in samples of medicinal plants and phytomedicines. The precision of the method was determined in terms of the percentage of the variation coefficient. The LOD and LOQ values of each analyte were calculated as the analyte concentration that corresponded to three and ten times, respectively, the standard deviation of ten independent measurements of the blank, divided by the slope of the calibration curve. To study the matrix effect, standard curves were prepared in dilute acid $\left(3 \mathrm{~mol} \mathrm{~L}^{-1} \mathrm{HNO}_{3}\right.$ ) from solutions of the digested samples. After, the measurements of emission intensities by ICP OES were performed, the slope coefficients were obtained from analytical curves. 


\section{Results and Discussion}

\section{Analytical performance}

A recovery test of the analytical procedure was carried out for the elements under study in a plant sample (Anemopaegma arvense Vell. ("catuaba")) by spiking (5 $\mu \mathrm{g}$ of each analyte) the analyzed samples with aliquots of metal standards and then reanalyzing the samples. This sample was chosen for this test due to its available mass. Acceptable recoveries (>95\%) were obtained for the studied elements. The obtained recovery values, in the range of 95 to $105 \%$, showed that there are no signs of systematic errors due to operation effects of the added analyte, such as losses during the process. The results are given in Table 2 .

The accuracy of the determinations was evaluated by the analysis of spinach leaves (CRM 1570a). The results (Table 3) showed good agreement with the reference values of the CRM sample for $\mathrm{Cd}, \mathrm{Cu}, \mathrm{Mn}, \mathrm{Ni}$ and $\mathrm{Zn}$.

The LOD and LOQ values were determined according to IUPAC (International Union of Pure and Applied Chemistry) recommendations, using standard deviation of blank solution measurements and the slope of the calibration curve. The LODs and LOQs values obtained for $\mathrm{Ca}, \mathrm{Cd}, \mathrm{Co}, \mathrm{Cr}, \mathrm{Cu}, \mathrm{Fe}, \mathrm{Mg}, \mathrm{Mn}, \mathrm{Ni}, \mathrm{Pb}, \mathrm{Se}, \mathrm{V}$ and $\mathrm{Zn}$ determined by ICP OES are shown in Table 4. The obtained LOD is similar to or better than those found for some methods reported in the literature to determine minerals in medicinal plants and phytomedicines.

Precision was examined under repeatability and reproducibility conditions. For the reproducibility examination, two different analysts were prepared on different days, the same CRM1570a samples. In the precision test, the average $\mathrm{RSD}(\%$, relative standard deviation) was calculated for all investigated trace metals by ICP OES. Precision was assessed and RSD values lower than $10 \%$ indicated the good precision of this method. The LOQ value is the lowest concentration that can be determined with acceptable laboratory reproducibility
Table 2. Addition recovery test ( $5 \mu \mathrm{g}$ ) on "catuaba" in order to determine the performance of the digestion procedure by microwave radiation $(n=3)$

\begin{tabular}{|c|c|c|c|}
\hline Analyte & Added / $\mu \mathrm{g}$ & Determined / $\mu \mathrm{g}$ & Recovery / \% \\
\hline$\overline{\mathrm{Al}}$ & $\begin{array}{l}0 \\
5\end{array}$ & $\begin{array}{c}\text { n.d. } \\
4.92 \pm 1.60\end{array}$ & $\begin{array}{l}- \\
98\end{array}$ \\
\hline $\mathrm{Ba}$ & $\begin{array}{l}0 \\
5\end{array}$ & $\begin{array}{c}\text { n.d. } \\
4.85 \pm 0.73\end{array}$ & $\begin{array}{c}- \\
97\end{array}$ \\
\hline $\mathrm{Ca}$ & $\begin{array}{l}0 \\
5\end{array}$ & $\begin{array}{l}255.14 \pm 0.32 \\
260.07 \pm 0.51\end{array}$ & $\begin{array}{c}- \\
100\end{array}$ \\
\hline $\mathrm{Cd}$ & $\begin{array}{l}0 \\
5\end{array}$ & $\begin{array}{c}\text { n.d. } \\
5.01 \pm 0.22\end{array}$ & $\begin{array}{c}- \\
100\end{array}$ \\
\hline $\mathrm{Cr}$ & $\begin{array}{l}0 \\
5\end{array}$ & $\begin{array}{c}\text { n.d. } \\
4.96 \pm 0.18\end{array}$ & $\begin{array}{c}- \\
99\end{array}$ \\
\hline Co & $\begin{array}{l}0 \\
5\end{array}$ & $\begin{array}{c}\text { n.d. } \\
4.89 \pm 0.40\end{array}$ & $\begin{array}{l}- \\
98\end{array}$ \\
\hline $\mathrm{Cu}$ & $\begin{array}{l}0 \\
5\end{array}$ & $\begin{array}{l}0.36 \pm 0.04 \\
5.42 \pm 0.13\end{array}$ & $\begin{array}{c}- \\
101\end{array}$ \\
\hline $\mathrm{Fe}$ & $\begin{array}{l}0 \\
5\end{array}$ & $\begin{array}{c}7.05 \pm 0.03 \\
11.83 \pm 0.85\end{array}$ & $\overline{-}$ \\
\hline $\mathrm{Mg}$ & $\begin{array}{l}0 \\
5\end{array}$ & $\begin{array}{l}248.45 \pm 1.03 \\
249.26 \pm 0.98\end{array}$ & - \\
\hline Mn & $\begin{array}{l}0 \\
5\end{array}$ & $\begin{array}{l}17.76 \pm 1.03 \\
21.85 \pm 0.56\end{array}$ & $\begin{array}{l}- \\
96\end{array}$ \\
\hline Мо & $\begin{array}{l}0 \\
5\end{array}$ & $\begin{array}{c}\text { n.d. } \\
4.77 \pm 1.40\end{array}$ & $\begin{array}{c}- \\
95\end{array}$ \\
\hline $\mathrm{Pb}$ & $\begin{array}{l}0 \\
5\end{array}$ & $\begin{array}{c}\text { n.d. } \\
4.83 \pm 1.72\end{array}$ & $\begin{array}{l}- \\
97\end{array}$ \\
\hline $\mathrm{Se}$ & $\begin{array}{l}0 \\
5\end{array}$ & $\begin{array}{c}\text { n.d. } \\
4.99 \pm 0.83\end{array}$ & $\begin{array}{c}- \\
99\end{array}$ \\
\hline $\mathrm{Ni}$ & $\begin{array}{l}0 \\
5\end{array}$ & $\begin{array}{c}\text { n.d. } \\
5.07 \pm 0.48\end{array}$ & $\begin{array}{c}- \\
101\end{array}$ \\
\hline V & $\begin{array}{l}0 \\
5\end{array}$ & $\begin{array}{c}\text { n.d. } \\
4.87 \pm 0.31\end{array}$ & $\begin{array}{c}- \\
97\end{array}$ \\
\hline $\mathrm{Zn}$ & $\begin{array}{l}0 \\
5\end{array}$ & $\begin{array}{c}4.84 \pm 0.05 \\
10.31 \pm 0.37\end{array}$ & $\begin{array}{c}- \\
105\end{array}$ \\
\hline
\end{tabular}

n.d.: not determined.

and trueness. The values obtained for LOD and LOQ were similar for all three procedures proposed for treatment samples. However, lower values were obtained for CD and MW procedures, suggesting that both are effective in the treatment with medicinal plants and phytomedicine samples before analysis by ICP OES. The closed-vessel

Table 3. Analysis of spinach leaves (certified reference material CRM 1570a) by ICP OES after dry ashing, conventional and microwave radiation procedures (mean \pm standard deviation, $\mathrm{n}=3,95 \%$ confidence level)

\begin{tabular}{|c|c|c|c|c|c|c|c|}
\hline \multirow[b]{2}{*}{ Element } & \multicolumn{3}{|c|}{ Dry ashing } & \multicolumn{2}{|c|}{ Conventional (wet digestion) } & \multicolumn{2}{|c|}{ Microwave radiation (wet digestion) } \\
\hline & $\begin{array}{c}\text { Certified value / } \\
\qquad\left(\mu \mathrm{g} \mathrm{g}^{-1}\right)\end{array}$ & $\begin{array}{c}\text { Determined / } \\
\left(\mu \mathrm{g} \mathrm{g}^{-1}\right)\end{array}$ & Recovery / \% & $\begin{array}{c}\text { Determined / } \\
\left(\mu \mathrm{g} \mathrm{g}^{-1}\right)\end{array}$ & Recovery / \% & $\begin{array}{l}\text { Determined / } \\
\left(\mu \mathrm{g} \mathrm{g}^{-1}\right)\end{array}$ & Recovery / \% \\
\hline $\mathrm{Cd}$ & $2.89 \pm 0.07$ & $2.37 \pm 0.25$ & 82 & $2.68 \pm 0.10$ & 93 & $2.72 \pm 0.12$ & 94 \\
\hline $\mathrm{Cu}$ & $12.2 \pm 0.60$ & $12.8 \pm 0.97$ & 105 & $12.4 \pm 1.03$ & 102 & $12.3 \pm 0.05$ & 101 \\
\hline $\mathrm{Mn}$ & $75.9 \pm 1.90$ & $69.8 \pm 4.10$ & 92 & $76.2 \pm 1.80$ & 100 & $75.6 \pm 0.80$ & 100 \\
\hline $\mathrm{Ni}$ & $2.14 \pm 0.10$ & $2.42 \pm 0.13$ & 113 & $2.18 \pm 0.33$ & 102 & $2.12 \pm 0.06$ & 99 \\
\hline $\mathrm{Zn}$ & $82.00 \pm 3.00$ & $84.0 \pm 6.02$ & 102 & $81.5 \pm 4.15$ & 99 & $83.7 \pm 0.15$ & 102 \\
\hline
\end{tabular}


Table 4. Limits of detection (LOD) and of quantification (LOQ) for $\mathrm{Ca}, \mathrm{Cd}, \mathrm{Co}, \mathrm{Cr}, \mathrm{Cu}, \mathrm{Fe}, \mathrm{Mg}, \mathrm{Mn}, \mathrm{Ni}, \mathrm{Pb}, \mathrm{Se}, \mathrm{V}$ and $\mathrm{Zn}$ determined by ICP OES after dry ashing, conventional and microwave radiation procedures

\begin{tabular}{|c|c|c|c|c|c|c|c|c|c|c|c|c|c|}
\hline & $\begin{array}{c}\mathrm{Ca} / \\
\left(\mathrm{mg} \mathrm{L}^{-1}\right)\end{array}$ & $\begin{array}{c}\mathrm{Cd} / \\
\left(\mu \mathrm{g} \mathrm{L}^{-1}\right)\end{array}$ & $\begin{array}{c}\mathrm{Co} / \\
\left(\mu \mathrm{g} \mathrm{L}^{-1}\right)\end{array}$ & $\begin{array}{c}\mathrm{Cr} / \\
\left(\mu \mathrm{g} \mathrm{L}^{-1}\right)\end{array}$ & $\begin{array}{c}\mathrm{Cu} / \\
\left(\mu \mathrm{g} \mathrm{L}^{-1}\right)\end{array}$ & $\begin{array}{c}\mathrm{Fe} / \\
\left(\mu \mathrm{g} \mathrm{L}^{-1}\right)\end{array}$ & $\begin{array}{c}\mathrm{Mg} / \\
\left(\mathrm{mg} \mathrm{L}^{-1}\right)\end{array}$ & $\begin{array}{c}\mathrm{Mn} / \\
\left(\mu \mathrm{g} \mathrm{L}^{-1}\right)\end{array}$ & $\begin{array}{c}\mathrm{Ni} / \\
\left(\mu \mathrm{g} \mathrm{L}^{-1}\right)\end{array}$ & $\begin{array}{c}\mathrm{Pb} / \\
\left(\mu \mathrm{g} \mathrm{L}^{-1}\right)\end{array}$ & $\begin{array}{c}\mathrm{Se} / \\
\left(\mu \mathrm{g} \mathrm{L}^{-1}\right)\end{array}$ & $\begin{array}{c}\mathrm{V} / \\
\left(\mu \mathrm{g} \mathrm{L}^{-1}\right)\end{array}$ & $\begin{array}{c}\mathrm{Zn} / \\
\left(\mu \mathrm{g} \mathrm{L}^{-1}\right)\end{array}$ \\
\hline & \multicolumn{13}{|c|}{ Microwave radiation (wet digestion) } \\
\hline LOD & 0.37 & 0.10 & 0.16 & 0.23 & 0.35 & 0.15 & 0.08 & 0.02 & 0.47 & 0.39 & 0.31 & 0.44 & 0.10 \\
\hline \multirow[t]{2}{*}{ LOQ } & 1.23 & 0.34 & 0.53 & 0.77 & 1.17 & 0.52 & 0.27 & 0.07 & 1.56 & 1.29 & 1.03 & 1.47 & 0.36 \\
\hline & \multicolumn{13}{|c|}{ Conventional (wet digestion) } \\
\hline LOD & 0.39 & 0.12 & 0.14 & 0.22 & 0.33 & 0.18 & 0.07 & 0.03 & 0.44 & 0.36 & 0.33 & 0.42 & 0.11 \\
\hline \multirow[t]{2}{*}{ LOQ } & 1.27 & 0.37 & 0.47 & 0.70 & 1.10 & 0.60 & 0.23 & 0.10 & 1.47 & 1.20 & 1.10 & 1.40 & 0.37 \\
\hline & \multicolumn{13}{|c|}{ Dry ashing } \\
\hline LOD & 0.51 & 0.16 & 0.22 & 0.35 & 0.56 & 0.27 & 0.13 & 0.05 & 0.59 & 0.43 & 0.45 & 0.53 & 0.15 \\
\hline LOQ & 1.70 & 0.53 & 0.74 & 1.14 & 1.86 & 0.90 & 0.43 & 0.17 & 1.93 & 1.42 & 1.50 & 1.76 & 0.51 \\
\hline
\end{tabular}

microwave-assisted wet digestion was preferred due to its accuracy with respect to both time and recovery values (recovery from 94 to $102 \%$ ). If the analyzed concentration levels of the most common matrix constituents of the certified reference material and the accuracy of the present method are considered together, it can be concluded that the proposed method is free from the interference of various constituents. Furthermore, MW was selected due to its reduced contamination, increasing efficiency of the decomposition process, lower residual acidity and reduced time required for digestion.

In bioanalysis, matrix components present in biological samples can affect the response of the analyte. The slopes of the calibration curves for each element do not show significant variations, for $95 \%$ confidence level. These results showed that matrix effect is not significant for the measures in ICP OES under the selected operating conditions.

Sample digestion efficiency is the critical step affecting analytical results for multielement determinations by ICP OES techniques. ${ }^{33}$ The digestion procedure was evaluated by comparing the residual carbon content, the residual acidity of the digests and the element recoveries by analyzing the CRM 1570a material. In general, the digestion of the solutions appeared to be the clearest, i.e., free from particles in suspension. The residual carbon contents ranged from $3.00 \pm 0.40 \%(n=3)$. The residual acidities obtained after the digestions was $2.5 \pm 0.5,1.7 \pm 0.4$ and $1.5 \pm 0.5 \mathrm{~mol} \mathrm{~L}^{-1}$ for DA, CD and MW procedures, respectively. This content shows a good efficiency of digestion of the organic matter of samples of medicinal plants and phytomedicines using the proposed sample preparation methods. Under these conditions, characteristics of simplicity, low cost and shorter analysis time for the procedures proposed, the MW method was selected.

\section{Analytical application in medicinal plants and phytomedicines}

The contents $\left(\mu \mathrm{g} \mathrm{g}^{-1}\right)$ of the 16 elements (Al, Ba, Ca, $\mathrm{Cd}, \mathrm{Co}, \mathrm{Cr}, \mathrm{Cu}, \mathrm{Fe}, \mathrm{Mg}, \mathrm{Mn}, \mathrm{Mo}, \mathrm{Ni}, \mathrm{Pb}, \mathrm{Se}, \mathrm{Sn}, \mathrm{V}$ and $\mathrm{Zn}$ ) in various medicinal plants and phytomedicines were determined using ICP OES, representing the mean of the replicate analysis. All analyzed samples contain $\mathrm{Ca}, \mathrm{Cu}$, $\mathrm{Fe}, \mathrm{Mg}, \mathrm{Mn}$ and $\mathrm{Zn}$ (Table 5). Co was determined in two samples: Hypericum perforatum L. (St. John's wort) and Uncaria tomentosa (cat's caw); and $\mathrm{Ni}$ has been quantified in only three samples: Hypericum perforatum L. (St. John's wort), Uncaria tomentosa (cat's caw) and Euterpe oleracea Mart. (açaí). Some elements such as $\mathrm{Al}, \mathrm{Ba}, \mathrm{Cd}, \mathrm{Cr}$, $\mathrm{Mo}, \mathrm{Pb}, \mathrm{Se}$ and $\mathrm{V}$ showed values below LOD, but good recovery percentage after the addition (spike) of each metal (1.0 $\mathrm{mg} \mathrm{L}^{-1}$ ) into the samples (Table 2).

The concentrations of $\mathrm{Ca}, \mathrm{Cu}, \mathrm{Fe}, \mathrm{Mg}, \mathrm{Mn}$ and $\mathrm{Zn}$ widely ranged, based on the samples. The contents of trace and essential elements detected in various samples were in the range from 100.71 to $462.20 \mu \mathrm{g} \mathrm{g}^{-1}$ for $\mathrm{Ca}$, from 0.32 to $7.82 \mu \mathrm{g} \mathrm{g}^{-1}$ for $\mathrm{Cu}$, from 2.74 to $18.03 \mu \mathrm{g} \mathrm{g}^{-1}$ for $\mathrm{Fe}$, from 18.40 to $521.28 \mu \mathrm{g} \mathrm{g}{ }^{-1}$ for $\mathrm{Mg}$, from 0.17 to $55.14 \mu \mathrm{g} \mathrm{g}^{-1}$ for Mn and from 2.96 to $20.92 \mu \mathrm{g} \mathrm{g}^{-1}$ for $\mathrm{Zn}$. For the phytomedicine kawa-kawa, Mn showed a value below LOD. In this study, Co was determined in two samples, Hypericum perforatum L. (St. John's wort, $0.540 \mu \mathrm{g} \mathrm{g}^{-1}$ ), Uncaria tomentosa (cat's caw, $0.851 \mu \mathrm{g} \mathrm{g}^{-1}$ ), and Ni has been quantified in only three samples: Hypericum perforatum $\mathrm{L}$. (St. John's wort, $1.246 \mu \mathrm{g} \mathrm{g}^{-1}$ ), Uncaria tomentosa (cat's caw, $0.922 \mu \mathrm{g} \mathrm{g}^{-1}$ ) and Euterpe oleracea Mart. (açaí, $0.558 \mu \mathrm{g} \mathrm{g}^{-1}$ ).

Principal component analysis (PCA) was performed using the software Statistica 7.0. The first two components (PC1 and PC2) describe $81.19 \%$ of the total variance. Thus, they were chosen to model the data. The elements 
Table 5. Trace element determinations in samples of medicinal plants and phytomedicines (mean \pm standard deviation, $\mathrm{n}=3,95 \%$ confidence level)

\begin{tabular}{|c|c|c|c|c|c|c|c|}
\hline & Procedure & $\begin{array}{c}\mathrm{Ca} / \\
\left(\mu \mathrm{g} \mathrm{g}^{-1}\right)\end{array}$ & $\begin{array}{c}\mathrm{Cu} / \\
\left(\mu \mathrm{g} \mathrm{g}^{-1}\right)\end{array}$ & $\begin{array}{c}\mathrm{Fe} / \\
\left(\mu \mathrm{g} \mathrm{g}^{-1}\right)\end{array}$ & $\begin{array}{c}\mathrm{Mg} / \\
\left(\mu \mathrm{g} \mathrm{g}^{-1}\right)\end{array}$ & $\begin{array}{c}\mathrm{Mn} / \\
\left(\mu \mathrm{g} \mathrm{g}^{-1}\right)\end{array}$ & $\begin{array}{c}\mathrm{Zn} / \\
\left(\mu \mathrm{g} \mathrm{g}^{-1}\right)\end{array}$ \\
\hline \multirow{3}{*}{$\begin{array}{l}\text { Maytenus ilicifolia Mart. ex Reiss } \\
\text { ("espinheira santa") }\end{array}$} & DA & $215.44 \pm 4.52$ & $0.32 \pm 0.03$ & $11.30 \pm 0.45$ & $318.45 \pm 2.31$ & $32.05 \pm 0.11$ & $3.98 \pm 0.19$ \\
\hline & $\mathrm{CD}$ & $233.34 \pm 3.01$ & $0.42 \pm 0.08$ & $12.01 \pm 0.70$ & $343.91 \pm 0.75$ & $32.45 \pm 0.09$ & $4.21 \pm 0.10$ \\
\hline & MW & $275.62 \pm 0.71$ & $0.45 \pm 0.13$ & $13.83 \pm 0.26$ & $343.20 \pm 0.52$ & $33.91 \pm 0.10$ & $4.26 \pm 0.08$ \\
\hline \multirow{3}{*}{$\begin{array}{l}\text { Piper methysticum G. Foster } \\
\text { (kawa-kawa) }\end{array}$} & DA & $100.71 \pm 1.12$ & $6.02 \pm 0.30$ & $2.84 \pm 0.28$ & $18.40 \pm 0.36$ & $<0.02$ & $2.96 \pm 0.09$ \\
\hline & $\mathrm{CD}$ & $108.10 \pm 1.12$ & $6.70 \pm 0.20$ & $3.50 \pm 0.32$ & $19.33 \pm 0.90$ & $<0.02$ & $3.20 \pm 0.20$ \\
\hline & MW & $113.17 \pm 2.15$ & $6.87 \pm 0.15$ & $2.91 \pm 0.12$ & $18.88 \pm 0.45$ & $<0.02$ & $2.98 \pm 0.11$ \\
\hline \multirow{3}{*}{$\begin{array}{l}\text { Hypericum perforatum } \mathrm{L} \text {. } \\
\text { (St. John's wort) }\end{array}$} & $\mathrm{DA}$ & $396.70 \pm 0.90$ & $0.46 \pm 0.09$ & $5.82 \pm 0.12$ & $428.78 \pm 1.30$ & $8.83 \pm 0.08$ & $17.39 \pm 0.30$ \\
\hline & $\mathrm{CD}$ & $431.10 \pm 0.12$ & $0.55 \pm 0.07$ & $6.01 \pm 0.05$ & $441.22 \pm 1.05$ & $9.03 \pm 0.10$ & $18.25 \pm 0.06$ \\
\hline & MW & $437.12 \pm 0.64$ & $0.52 \pm 0.06$ & $5.98 \pm 0.07$ & $452.13 \pm 1.02$ & $9.32 \pm 0.09$ & $20.92 \pm 0.46$ \\
\hline \multirow{3}{*}{$\begin{array}{l}\text { Pfaffia glomerata (Spreng.) Pedersen } \\
\text { (Brazilian ginseng) }\end{array}$} & DA & $318.15 \pm 1.52$ & $2.84 \pm 0.25$ & $17.32 \pm 0.10$ & $518.60 \pm 0.35$ & $53.19 \pm 0.42$ & $17.66 \pm 0.42$ \\
\hline & $\mathrm{CD}$ & $356.18 \pm 1.40$ & $3.22 \pm 0.11$ & $18.03 \pm 0.07$ & $521.28 \pm 0.40$ & $54.67 \pm 0.10$ & $18.32 \pm 0.08$ \\
\hline & MW & $358.32 \pm 1.23$ & $3.41 \pm 0.07$ & $17.53 \pm 0.06$ & $517.31 \pm 0.54$ & $55.14 \pm 0.20$ & $17.95 \pm 0.04$ \\
\hline \multirow{3}{*}{$\begin{array}{l}\text { Uncaria tomentosa } \\
\text { (cat's caw) }\end{array}$} & $\mathrm{DA}$ & $452.30 \pm 2.40$ & $7.30 \pm 0.08$ & $6.70 \pm 0.06$ & $130.63 \pm 1.05$ & $3.30 \pm 0.08$ & $14.75 \pm 0.12$ \\
\hline & $\mathrm{CD}$ & $462.20 \pm 0.90$ & $7.60 \pm 0.06$ & $7.30 \pm 0.02$ & $134.70 \pm 0.50$ & $3.52 \pm 0.10$ & $15.10 \pm 0.08$ \\
\hline & MW & $461.87 \pm 1.01$ & $7.82 \pm 0.06$ & $7.49 \pm 0.13$ & $136.12 \pm 0.47$ & $3.57 \pm 0.17$ & $15.22 \pm 0.10$ \\
\hline \multirow{3}{*}{$\begin{array}{l}\text { Rhamnus purshiana } \\
\text { (sacred bark) }\end{array}$} & $\mathrm{DA}$ & $130.88 \pm 0.52$ & $2.47 \pm 0.53$ & $5.32 \pm 0.17$ & $258.00 \pm 0.83$ & $4.93 \pm 0.94$ & $10.83 \pm 0.53$ \\
\hline & $\mathrm{CD}$ & $131.50 \pm 0.01$ & $2.60 \pm 0.02$ & $5.91 \pm 0.03$ & $266.02 \pm 0.05$ & $5.24 \pm 0.13$ & $11.02 \pm 0.24$ \\
\hline & MW & $134.90 \pm 0.04$ & $3.40 \pm 0.01$ & $6.36 \pm 0.02$ & $270.02 \pm 0.03$ & $5.39 \pm 0.07$ & $12.10 \pm 0.09$ \\
\hline \multirow{3}{*}{$\begin{array}{l}\text { Ptychopetalum olacoides Bentham } \\
\text { ("marapuama"/potency wood) }\end{array}$} & $\mathrm{DA}$ & $190.21 \pm 1.12$ & $6.47 \pm 0.05$ & $2.74 \pm 0.10$ & $159.80 \pm 1.20$ & $0.17 \pm 0.02$ & $3.06 \pm 0.10$ \\
\hline & $\mathrm{CD}$ & $193.24 \pm 0.82$ & $6.52 \pm 0.20$ & $2.83 \pm 0.05$ & $165.43 \pm 1.50$ & $0.29 \pm 0.02$ & $3.25 \pm 0.02$ \\
\hline & MW & $194.13 \pm 0.54$ & $6.54 \pm 0.14$ & $2.78 \pm 0.06$ & $166.18 \pm 0.92$ & $0.26 \pm 0.04$ & $3.27 \pm 0.07$ \\
\hline \multirow{3}{*}{$\begin{array}{l}\text { Anemopaegma arvense Vell. } \\
\text { ("catuaba") }\end{array}$} & $\mathrm{DA}$ & $248.30 \pm 1.08$ & $0.32 \pm 0.02$ & $6.40 \pm 0.13$ & $241.40 \pm 0.08$ & $16.84 \pm 0.08$ & $4.47 \pm 0.09$ \\
\hline & $\mathrm{CD}$ & $251.40 \pm 0.50$ & $0.40 \pm 0.01$ & $7.01 \pm 0.04$ & $246.44 \pm 2.90$ & $17.50 \pm 0.01$ & $4.60 \pm 0.05$ \\
\hline & MW & $255.14 \pm 0.32$ & $0.36 \pm 0.04$ & $7.05 \pm 0.03$ & $248.45 \pm 1.03$ & $17.76 \pm 0.04$ & $4.84 \pm 0.05$ \\
\hline \multirow{3}{*}{$\begin{array}{l}\text { Euterpe oleracea Mart. } \\
\text { (açaí) }\end{array}$} & DA & $185.60 \pm 0.95$ & $1.03 \pm 0.07$ & $8.31 \pm 0.09$ & $152.90 \pm 1.24$ & $23.60 \pm 0.07$ & $7.02 \pm 0.15$ \\
\hline & $\mathrm{CD}$ & $187.63 \pm 0.70$ & $1.20 \pm 0.10$ & $8.60 \pm 1.10$ & $156.70 \pm 0.20$ & $24.20 \pm 0.04$ & $7.33 \pm 0.03$ \\
\hline & MW & $186.27 \pm 0.54$ & $1.15 \pm 0.07$ & $9.52 \pm 0.74$ & $155.47 \pm 0.17$ & $23.01 \pm 0.06$ & $7.55 \pm 0.02$ \\
\hline
\end{tabular}

Procedures: dry ashing (DA), conventional (CD) and microwave radiation (MW).

$\mathrm{Mg}, \mathrm{Fe}$ and $\mathrm{Mn}$ are the dominant variables in the first principal component (PC1) and represent $57.25 \%$ of the total variance. The second principal component (PC2) accounts for $23.94 \%$ of the total variance, and $\mathrm{Ca}, \mathrm{Zn}$ and $\mathrm{Cu}$ are dominant variables. Figure 1a shows the score plot of the first two components and Figure $1 \mathrm{~b}$ the chart for the loading elements in PC1 and PC2. It was observed that samples with higher concentrations of $\mathrm{Mg}, \mathrm{Fe}$ and $\mathrm{Mn}$ are those having lower scores for PC1, such as Brazilian ginseng (BG) samples, using different preparation procedures. In contrast, kawa-kawa (KK) and potency wood (PW) samples are those with the lowest concentrations for these elements. Samples with lower scores in PC2, cat's caw (CC), followed by St. John's wort (JW), have high concentrations of $\mathrm{Zn}$ and $\mathrm{Ca}$. On the other hand, samples with positive weight in $\mathrm{PC} 2$ have lower concentrations of these elements. Therefore, it is observed that the variance in terms of concentrations of various elements in the sample overlaps the variance between preparation procedures for each sample, i.e., among samples with different preparation procedures within the next data set.

The values of the $t$-test were calculated for the pairs $\mathrm{DA} / \mathrm{CD}, \mathrm{DA} / \mathrm{MW}$ and $\mathrm{CD} / \mathrm{MW}$. It was considered as a null hypothesis when the concentrations provided by different procedures were statistically equal. The concentrations of $\mathrm{Ca}, \mathrm{Cu}, \mathrm{Fe}, \mathrm{Mg}$ obtained by DA/CD and DA/MW procedures showed statistical differences $(p<0.05)$. Based on student's $t$-test, there were no significant differences at the $95 \%$ confidence level for $\mathrm{Ca}, \mathrm{Cu}, \mathrm{Fe}, \mathrm{Mg}, \mathrm{Mn}$ and $\mathrm{Zn}$, compared to $\mathrm{CD} / \mathrm{MW}$.

In recent studies in Argentina, Gomez et al. ${ }^{15}$ used atomic methodologies such as flame atomic absorption spectrometry (FAAS), electrothermal atomic absorption spectrometry (ETAAS) and capillary electrophoresis (CE) for the determination of mineral content in pharmaceutical quality control of phytomedicines. $\mathrm{Ca}, \mathrm{Cu}, \mathrm{K}, \mathrm{Li}, \mathrm{Mg}$, $\mathrm{Mn}, \mathrm{Na}, \mathrm{Ni}$, and $\mathrm{Zn}$ were detected in phytopharmaceutical derivatives of Hypericum perforatum, solid (dried herb, tablet) and liquid (tea, tincture) formulations. A few samples 
(a)

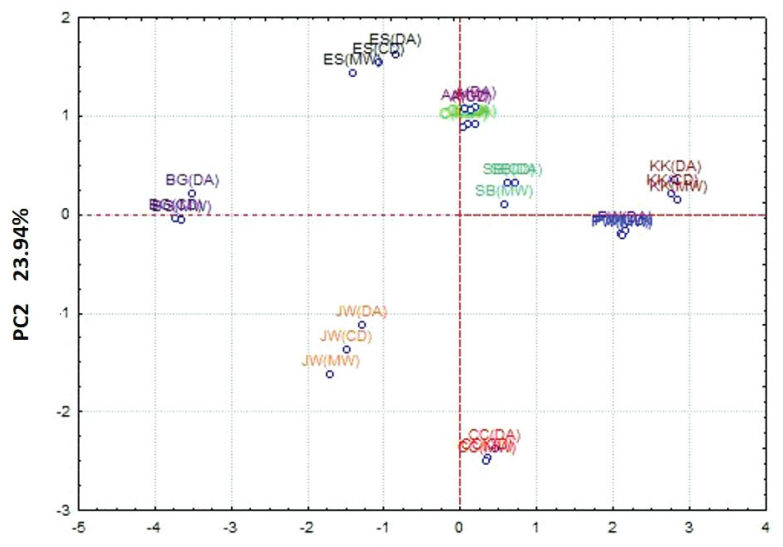

(b)

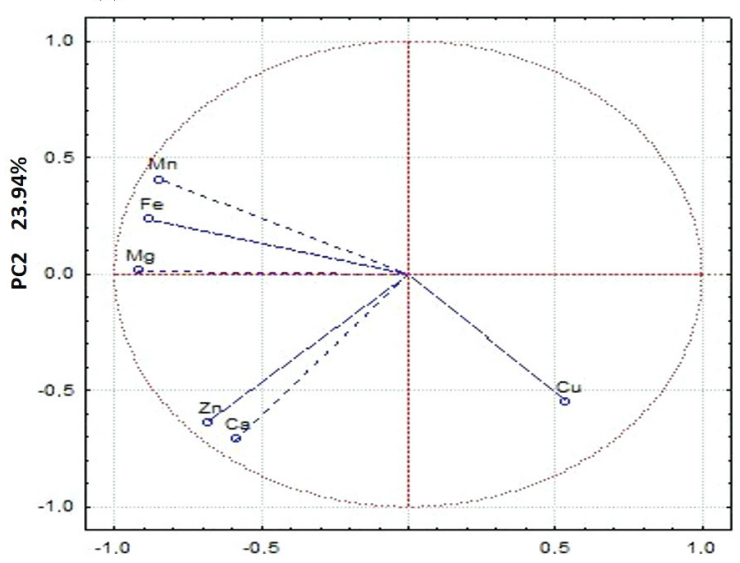

Figure 1. Principal component analysis (PCA) for trace element determinations in samples of medicinal plants and phytomedicines after dry ashing (DA), conventional (CD) and microwave radiation (MW) procedures. (a) Score plot of the first two components and (b) the chart for the loading elements in PC1 and PC2. BG = Pfaffia glomerata (Spreng.) Pedersen (Brazilian ginseng), ES = Maytenus ilicifolia Mart. ex Reiss ("espinheira santa"), JW = Hypericum perforatum L (St. John's wort), $\mathrm{CC}=$ Uncaria tomentosa (cat's caw), AA = Anemopaegma arvense Vell. ("catuaba"), CÇ = Euterpe oleracea Mart. (açaí), SB = Rhamnus purshiana (sacred bark), $\mathrm{PW}=$ Ptychopetalum olacoides Bentham ("marapuama"/potency wood), and KK = Piper methysticum G. Foster (kawa-kawa).

contained very small quantities of nickel $\left(0.04\right.$ to $0.49 \mu \mathrm{g} \mathrm{g}^{-1}$ and 0.51 to $0.96 \mu \mathrm{g} \mathrm{g}^{-1}$ for solid and liquid samples, respectively). This can be attributed to nickel as one of the most mobile and bioavailable heavy metal ions that may be present in both industrially contaminated and pristine soils. ${ }^{34}$ The results obtained in this study were in agreement with the study mentioned above since the concentration of $\mathrm{Zn}$ (19.7 to $25.2 \mu \mathrm{g} \mathrm{g}^{-1}$ ) and Mn (7.77 to $9.82 \mu \mathrm{g} \mathrm{g}^{-1}$ ) were detected. In addition, Ni has been quantified in only three samples: Hypericum perforatum L. (St. John's wort, $1.246 \mu \mathrm{g} \mathrm{g}^{-1}$ ), Uncaria tomentosa (cat's caw, $0.922 \mu \mathrm{g} \mathrm{g}^{-1}$ ) and Euterpe oleracea Mart. (açaí, $0.558 \mu \mathrm{g} \mathrm{g}{ }^{-1}$ ).

In the United States, Bu et al. ${ }^{35}$ evaluated the concentrations of twelve elements $(\mathrm{Mg}, \mathrm{Al}, \mathrm{Ca}, \mathrm{V}, \mathrm{Cr}, \mathrm{Mn}$,
$\mathrm{Fe}, \mathrm{Co}, \mathrm{Ni}, \mathrm{Cu}, \mathrm{Zn}$ and $\mathrm{Cd}$ ) in six herbal supplements, Korean panax ginseng (Panax ginseng), golden seal (Hydrastis canadensis), ginger root (Zingiber officinale), St. John's wort (Hypericum perforatum), green tea (Camellia sinensis) and valerian root (Valeriana officinalis), by both laser ablation-inductively coupled plasma mass spectrometry (LA-ICP MS) and conventional closed-vessel digestion solution nebulization-ICP MS (SN-ICP MS). The results $\left(\mathrm{mg} \mathrm{kg}^{-1}\right)$ obtained for Korean panax ginseng (203-233 for $\mathrm{Ca}, 0.412-0.747$ for $\mathrm{Cu}, 4.66-5.27$ for $\mathrm{Fe}$, 688-712 for $\mathrm{Mg}, 0.435-0.499$ for $\mathrm{Mn}$ and 5.26-6.33 for $\mathrm{Zn}$ ) were not similar to those found in this study, since this species was different, Pfaffia glomerata (Spreng.) Pedersen (Brazilian ginseng). For Hypericum perforatum L. (St. John's wort), the results (in $\mathrm{mg} \mathrm{kg}^{-1}, 419-447$ for $\mathrm{Ca}, 7.77-9.82$ for $\mathrm{Mn}$ and 19.7-25.2 for $\mathrm{Zn}$ ) were similar to the ones observed in this study. $\mathrm{Al}, \mathrm{Cd}, \mathrm{Co}, \mathrm{Ni}$ and $\mathrm{V}$ were quantified by $\mathrm{Bu}$ et al. ${ }^{35}$ while, in this study, only $\mathrm{Ni}$ and $\mathrm{Co}$ were quantified. The other elements presented below LOD. It is noteworthy that these authors used mass spectrometry coupled to inductively coupled plasma (ICP MS), that is much used for elemental determination in different samples due to their characteristics, especially those related to multielement capacity, speed and high sensitivity. Moreover, the presence of such elements may be incorporated into the samples during the handling process and marketing, characterizing contamination.

Peake et al. ${ }^{36}$ studied the content of $\mathrm{Cu}$ (3.2 to $\left.8.1 \mu \mathrm{g} \mathrm{g}^{-1}\right), \mathrm{Zn}$ (15.6 to $24.3 \mu \mathrm{g} \mathrm{g}^{-1}$ ) and Mn (23.7 to $62.4 \mu \mathrm{g} \mathrm{g}^{-1}$ ) in New Zealand for ginseng (Panax Quinquefolius American) by ICP-MS. These results were similar to those of this study, although the species are different. Gordon et al..$^{37}$ determined $\mathrm{Na}, \mathrm{Mg}, \mathrm{P}, \mathrm{K}, \mathrm{Ca}, \mathrm{Mg}$, Fe and $\mathrm{Zn}$ in samples of açaí fruits (Euterpe oleracea Mart.) in three different maturity stages by high-performance liquid chromatography/electrospray ionization tandem mass spectrometry (HPLC/ESI-MS/MS) techniques. The results obtained (mg $100 \mathrm{~g}^{-1}, 423-962$ for $\mathrm{Ca}, 7.8-23.9$ for $\mathrm{Fe}, 172-397$ for $\mathrm{Mg}, 13.3-30.9$ for $\mathrm{Mn}$ and 1.2-2.1 for $\mathrm{Zn}$ ) were not similar to this study. The obtained açaí samples had no information about fruit maturity stage and, therefore, variations in the concentration of these elements can be justified.

Divrikli et al. ${ }^{38}$ evaluated the concentrations of trace metal $(\mathrm{Cu}, \mathrm{Cd}, \mathrm{Pb}, \mathrm{Ni}, \mathrm{Cr}, \mathrm{Fe}, \mathrm{Mn}$ and $\mathrm{Zn})$ levels in eleven different spices and herbal plant species from western Anatolia (Turkey) by atomic absorption spectrometry (FAAS). The authors point out that contamination was not a problem in the digestion procedure, as the level of the analyte ions in the blank digest were close to their limits of detection, although not highlighting the values for LOD 
in the study. $\mathrm{Cd}, \mathrm{Co}, \mathrm{Cr}$, and $\mathrm{Pb}$ were not determined in the recovery test and some samples. In this study, Ni showed values only for three samples: Hypericum perforatum $L$. (St. John's wort): $1.246 \mu \mathrm{g} \mathrm{g}^{-1}$; Uncaria tomentosa (cat's caw): $0.922 \mu \mathrm{g} \mathrm{g}^{-1}$ and Euterpe oleracea Mart. (açaí): $0.558 \mu \mathrm{g} \mathrm{g}^{-1}$. This fact can be attributed to differences in soil and absence of contamination, as proposed by Murch et al. ${ }^{34}$

Soylak et al. ${ }^{39}$ studied trace element contents of seven kinds of herbal plants and spice samples retailed in local markets in Kayseri, Turkey, by FAAS after digestion with $\mathrm{HNO}_{3} / \mathrm{H}_{2} \mathrm{O}_{2}$ mixture. The concentration ranges $\left(\mu \mathrm{g} \mathrm{g}^{-1}\right)$ for $\mathrm{Cu}$ (6.0-15.2), Ni (0-32.2), Fe (80.0-324.8), Mn (8.1-386.3) and $\mathrm{Zn}(13.1-36.2)$ were found. $\mathrm{Co}, \mathrm{Pb}$ and $\mathrm{Cr}$, in all the investigated samples, were found to be below the LOD value of FAAS. In this study, $\mathrm{Al}, \mathrm{Ba}, \mathrm{Cd}, \mathrm{Cr}, \mathrm{Mo}, \mathrm{Pb}, \mathrm{Se}$ and $\mathrm{V}$ showed values below the LOD value of ICP OES and were not detected in the analyzed medicinal plants and phytomedicines (Table 2).

No data was found in the literature for other analyzed species, regarding elemental composition. The results indicate that the studied medicinal plants and phytomedicines contain significant amounts of $\mathrm{Ca}, \mathrm{Cu}, \mathrm{Fe}, \mathrm{Mg}, \mathrm{Mn}$ and $\mathrm{Zn}$. Therefore, they can be a source of biologically important elements, supplementation with important therapeutic role in the physiological function. The nutrient content in medicinal plants depends on some variables (biotic and abiotic factors), such as air and soil temperature, light and humidity, planting time, genotype and concentration of nutrients in the soil, besides other geographical conditions. Additionally, other factors, such as drip irrigation, vertical conduction of plants and plastic cover, influence the absorption of nutrients. ${ }^{40}$ Ajasab et al. ${ }^{41}$ analyzed the content of some herbal species used in Nigeria and correlated the presence of $\mathrm{Na}, \mathrm{K}, \mathrm{Mg}$, $\mathrm{Ca}, \mathrm{Fe}, \mathrm{Mn}, \mathrm{Cu}, \mathrm{Pb}$ and $\mathrm{Zn}$ with therapeutic applications.

\section{Conclusions}

The concentrations of 16 elements were determined in nine samples of medicinal plants and phytomedicines by ICP OES following dry ashing and conventional and microwave-assisted digestion procedures. Microwave digestion followed by analysis by ICP OES has been shown to be a simple, fast and reliable method for the multielement determination in medicinal plants and phytomedicines, when compared to dry ashing and wet digestion (conventional). PCA was performed and it was observed that the variance in terms of concentrations of various elements in the sample overlaps the variance between preparation procedures for each sample. There were no significant differences at the $95 \%$ confidence level for $\mathrm{Ca}, \mathrm{Cu}, \mathrm{Fe}, \mathrm{Mg}, \mathrm{Mn}$ and $\mathrm{Zn}$, compared to $\mathrm{CD} / \mathrm{MW}$.
The proposed method for the determination of macro and microelements in medicinal plants and phytomedicines was efficient, with adequate values of limit of quantification and precision for the low concentration usually found in these samples. Among the determinations, the elements $\mathrm{Ca}, \mathrm{Cu}, \mathrm{Fe}$, $\mathrm{Mg}, \mathrm{Mn}$ and $\mathrm{Zn}$ were found in all of the analyzed samples. Co was determined in two samples: Hypericum perforatum $\mathrm{L}$. (St. John's wort) and Uncaria tomentosa (cat's caw) and $\mathrm{Ni}$ has been quantified in only three samples: Hypericum perforatum L. (St. John's wort), Uncaria tomentosa (cat's caw) and Euterpe oleracea Mart. (açaí). The studied procedures can be used in the pharmaceutical quality control of medicinal plants and phytomedicines.

\section{Acknowledgments}

The authors are grateful for the financial support received from Fundação de Amparo a Pesquisa do Estado da Bahia (FAPESB), Conselho Nacional de Desenvolvimento Científico e Tecnológico (CNPq), Coordenação de Aperfeiçoamento de Pessoal de Nível Superior (CAPES) and Herbarium Pharmaceutical Laboratory by donation of some samples.

\section{References}

1. World Health Organization (WHO); Traditional MedicineGrowing Needs and Potential; WHO Policy Perspective on Medicines, available at: http://apps.who.int/medicinedocs/en/d/ Js2293e/, accessed in June 2016.

2. Feet, C.; Ciência da Suplementação Alimentar; Sprint: Rio de Janeiro, Brazil, 2002.

3. World Health Organization(WHO); Regulatory Situation of Herbal Medicines - A Worldwide Review; Bulletin of the World Health Organization, available at: http://apps.who.int/medicinedocs/ pdf/whozip57e/whozip57e.pdf, accessed in June 2016.

4. Stanojkovic-Sebica, A.; Pivica, R.; Josica, D.; Dinica, Z.; Stanojkovicb, A.; J. Agr. Sci. 2015, 21, 317.

5. Esetlili, B. C.; Pekcan, T.; Çobanoglu, O.; Aydogdu, E.; Turan, S.; Anaç, D.; J. Agr. Sci. 2014, 20, 239.

6. Soetan, K. O.; Olaiya, C. O.; Oyewole, O. E.; Afr. J. Food Sci. 2010, 4, 200.

7. Ministério da Saúde (MS), Agência Nacional de Vigilância Sanitária (ANVISA); determina a dublicação do Guia para Validação de Métodos Analíticos e Bioanalíticos; Resolução No. 899, de 29 de maio de 2003, Brasil, available at: http:// portal.anvisa.gov.br/wps/wcm/connect/4983b0004745975da 005f43fbc4c6735/RE_899_2003_Determina+a+publica\%C3 $\% \mathrm{~A} 7 \% \mathrm{C} 3 \% \mathrm{~A} 3 \mathrm{o}+\mathrm{do}+\mathrm{Guia}+$ para+valida\%C3\%A7\%C3\%A3 o+de+m\%C3\%A9todos+anal\%C3\%ADticos+e+bioanal $\%$ C3 \%ADticos.pdf?MOD=AJPERES, accessed in April 2016. 
8. Giacomino, A.; Abollino, O.; Casanova, C.; La Gioia, C.; Magi, E.; Malandrino, M.; Microchem. J. 2015, 120, 6.

9. Filipiak-Szok, A.; Kurzawa, W.; Szłyk, E.; J. Trace Elem. Med. Bio. 2015, 30, 54.

10. Maghrabi, I. A.; Afr. J. Pharm. Pharmacol. 2014, 8, 893.

11. Zöllner, T.; Schwarz, M.; Braz. J. Pharmacog. 2013, 23, 1.

12. Oliveira, E.; J. Braz. Chem. Soc. 2003, 14, 174.

13. Marin, S.; Lacrimioara, S.; Cecilia, R.; J. Plant Develop. 2011, $18,87$.

14. Korn, M. G. A.; Boa Morte, E. S.; Santos, D. C. M. B.; Castro, J. T.; Barbosa, J. T. P.; Teixeira, A. P.; Fernandes, A. P.; Welz, B.; Santos, W. P. C.; Santos, E. B. G. N.; Korn, M.; Appl. Spectrosc. Rev. 2008, 43, 67.

15. Gomez, M. R.; Cerutti, S.; Olsina, R. A.; Silva, M. F.; Martinez, L. D.; J. Pharm. Biomed. Anal. 2004, 34, 569.

16. Hellings, J.; Adeloju, S. B.; Verheyen, T. V.; Microchem. J. 2013, 111, 62 .

17. Qing-hua, Y.; Li, Y.; Qing, W.; Xiao-Qin, M.; J. Saudi Chem. Soc. 2012, 16, 287.

18. Mandiwana, K. L.; Panichev, N.; Panicheva, S.; Food Chem. 2011, 129, 1839.

19. Kolachi, N. F.; Kazi, T. G.; Afridi, H. I.; Khan, S.; Wadhwa, S. K.; Shah, A. Q.; Shah, F.; Baig, J. A.; Sirajuddin; Food Chem. Toxicol. 2010, 48, 3327.

20. Soriano, S.; Pereira Netto, A. D.; Cassella, R. J.; Anal. Bioanal. Chem. 2007, 387, 1113.

21. Razic, S.; Onjia, A.; Dogo, S.; Slavkovic, L.; Popovic, A.; Talanta 2005, 67, 233.

22. Kalny, P.; Fijałek, Z.; Daszczuk, A.; Ostapczuk, P.; Sci. Total Environ. 2007, 381, 99.

23. Okem, A.; Southway, C.; Ndhlala, A. R.; Van Staden, J.; S. Afr. J. Bot. 2012, 82, 75.

24. Tokalioglu, S.; Food Chem. 2012, 134, 2504.

25. Trevizan, L. C.; Nobrega, J. A.; J. Braz. Chem. Soc. 2007, 18, 678.

26. National Research Council (NRC), Commitee on Scientific Assessment of Bullet Lead Elemental Composition Comparison; Forensic Analysis: Weighing Bullet Lead Evidence; National Academies Press: Washington, USA, 2004.
27. Ghanjaoui, M. E.; Cervera, M. L.; El Rhazi, M.; Guardia, M.; Food Chem. 2011, 125, 1309.

28. Gomez, M. R.; Cerutti, S.; Sombra, L. L.; Silva, M. F.; Martinez, L. D.; Food Chem. Toxicol. 2007, 45, 1060.

29. Krejkova, A.; Kahoun, D.; Chernohorsky, T.; Pouzar, M.; Food Chem. 2006, 98, 171.

30. Krampitz, P. D.; Barnes, K. W.; Atom. Spectrosc. 1998, 19, 43.

31. Official Methods of Analysis of AOAC International (OMA); Official Method 999.11: Determination of Lead, Cadmium, Copper, Iron and Zinc in Foods, Atomic Absorption Spectrometry after Dry Ashing; Official Methods of Analysis of AOAC International Maryland-AOAC International, Gaithersburg, USA, 2000.

32. Gouveia, S. T.; Silva, F. V.; Costa, L. M.; Nogueira, A. R. A.; Nóbrega, J. A.; Anal. Chim. Acta 2001, 445, 269.

33. Sucharova, J.; Suchara, I.; Anal. Chim. Acta 2006, 576, 163.

34. Murch, S.; Haq, K.; Rupasinghe, H. P.; Saxena, P. K.; Environ. Exp. Bot. 2003, 49, 251.

35. Bu, K.; Cizdziel, J. V.; Reidy, L.; Microchem. J. 2013, 106, 244.

36. Peake, B. M.; Tong, A. Y. C.; Wells, W. J.; Harraway, J. A.; Niven, B. E.; Weege, B.; LaFollette, D. J.; Forensic. Sci. Int. 2015, 251, 214.

37. Gordon, A.; Cruz, A. P. G.; Cabral, L. M. C.; Freitas, S. C.; Taxi, C. M. A. D.; Donangelo, C. M.; Mattietto, R. A.; Friedrich, M.; Matta, V. M.; Marx, F.; Food Chem. 2012, 133, 256.

38. Divrikli, U.; Horzum, N.; Soylak, M.; Elci, L.; Int. J. Food Sci. Technol. 2006, 41, 712.

39. Soylak, M.; Cihan, Z.; Yilmaz, E.; Environ. Monit. Assess. 2012, $184,3455$.

40. Fayad, J. A.; Fontes, P. C. R.; Cardoso, A. A.; Finger, F. L.; Ferreira, F. A.; Hortic. Bras. 2002, 20, 90.

41. Ajasab, A. M. O.; Bellob, M. O.; Ibrahimb, A. O.; Ogunwandea, I. A.; Olaworeb, N. O.; Food Chem. 2004, 85, 67.

Submitted: April 7, 2016

Published online: June 21, 2016 